\title{
ĐÁNH GIÁ HIÊ̂N TRẠNG MÔI TRƯờNG NƯỚC VÀ PHÂN VÙNG KHỐNG GIAN SẢN XUẤT MIẾN TẠI LÀNG NGHỀ ĐÔNG THỌ, THÁI BİNH
}

\author{
Phạm Thị Tố Oanh ${ }^{1}$
}

Tóm tắt: Đông Thọ với nghề phu chủ yếu là sản xuất miến dong, bên cạnh các lợi ich kinh tế mang lại, việc mở rộng sản xuất làm gia tăng luợng chất thải phát sinh. Nguyên nhân chủ yếu gây ô nhiễm là do nước thải sản xuất tại các hộ sản xuất miến. Hầu hết nuớc thải được thải trục tiếp ra môi truờng không qua xủ lý. Kết quả phân tích mẫu nuớc thải sản xuất so sánh với quy chuẩn cho phép (QCVN 40:2011/BTNMT), TSS cao hơn gấp 8,5 lần quy chuẩn, COD cao hơn 1,15 lần và $B O D_{5}$ cao gấp 2,22 lần. Hầu hết các mẫu nước mặt đều vuợt tiêu chuẩn cho phép (QCVN 08-

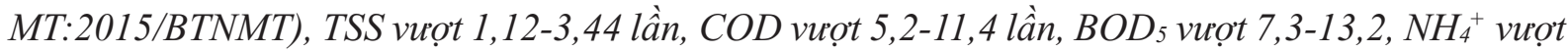
10 lần, $\mathrm{PO}_{4}^{3-}$ vurợt 2,07-2,5 lần, lượng oxy hòa tan trong nước khá thấp không đạt tiêu chuẩn. Nước ngầm tại khu vưc hai thôn Đoàn Kết và Thống Nhất bị ô nhiếm về chỉ số pemanganat và nitrat. Nghiên cứu đề xuất nhũ̃ng giải pháp phân vùng không gian sản xuất miến nhằm quản lý phòng ngùa và giảm thiểu ô nhiếm môi truờng.

Từ khóa: Ô nhiê̂m, phân vùng không gian, sản xuất miến, cộng đồng.

Ban Biên tập nhận bài: 20/2/2020 Ngày phản biện xong: 15/3/2020 Ngày đăng bài: 25/03/2020

\section{1. Đặt vấn đề}

Các làng nghề đã và đang đóng góp vai trò quan trọng đối với sự phát triển kinh tế xã hội Việt Nam, đặc biệt là khu vực kinh tế nông thôn [3]. Đông Thọ là một xã thuộc thành phố Thái Bình, tỉnh Thái Bình. Với nghề phụ chủ yếu là sản xuất miến dong, bên cạnh các lợi ích kinh tế mang lại, việc mở rộng sản xuất của làng nghề làm miến tại xã Đông Thọ cũng làm gia tăng lượng chất thải phát sinh [2]. Đặc trưng ô nhiễm của Đông Thọ là nước thải sản xuất. Thông thường nước thải sản xuất miến nói riêng và ngành sản xuất chế biến lương thực thực phẩm nói chung là có hàm lượng chất hữu cơ cao. Hiện nay, làng nghề chưa có quy hoạch khu vực sản xuất và môi trường sống phù hợp. Lượng nước thải hàng năm từ hoạt động sản xuất là rất lớn nhưng không được xử lý hoặc cũng có dẫn qua hệ thống xử lý nhưng hệ thống này hoạt động không hiệu quả, sau đó thải trực tiếp vào kênh mương, rồi đổ vào sông Trà Lý. Chính những

${ }^{1}$ Liên minh Hợp tác xã Việt Nam

Email:oanhpt@vca.org.vn hạn chế trên đã ảnh hưởng rất nhiều đến sự phát triển chung của làng nghề và tác động xấu đến môi trường tại địa phương. Xã Đông Thọ đang trên hành trình xây dựng nông thôn mới nên vấn đề bảo vệ môi trường xanh - sạch - đẹp, hoạt động sản xuất an toàn, các cơ sở sản xuất, kinh doanh đạt chỉ tiêu về môi trường đang rất được quan tâm [6,7].

Hiện nay, ở Việt Nam có một số công trình, đề án nghiên cứu về giải pháp quản lý nước thải sản xuất thực phẩm. Công trình nghiên cứu "Nghiên cứu xử lý nước thải sản xuất bún bằng phương pháp lọc kị khí kết hợp đĩa quay sinh học" của ThS. Bùi Thị Vụ - Khoa Môi trường, Trường Đại học Dân lập Hải Phòng, Đề tài: "Nghiên cứu xủ lý nước thái của làng nghề sản xuất miến dong trong cả nước bằng phưong pháp loc sinh hoc ngập nước" của Đại học Bách Khoa Hà Nội, đề tài "Nghiên cúu, đề xuất biện pháp sản xuất sạch hơn đối với các làng nghề chế biến thực phẩm tại Bắc Ninh" do Tiến sĩ Phạm Thị Tố Oanh nghiên (2006), "Quản lý môi trường làng nghề dựa vào cộng đồng, đề án 3 năm 2014 - 2016" của Liên minh hợp tác xã Việt 
Nam,.... Kết quả các nghiên cứu này chủ yếu tập trung vào đề xuất các công nghệ xử lý nước thải thực phẩm, chưa có nghiên cứu nào đưa ra giải pháp quản lý nước và phân vùng không gian sản xuất phù hợp đối với điều kiện sản xuất của làng nghề. Qua đó, xây dựng nếp sống theo hướng thân thiện với môi trường, góp phần phát triển xã hội bền vững, cụ thể hóa chủ trương, chính sách, pháp luật nhà nước về quản lý và xử lý nước thải sản xuất cải thiện môi trường sống của người dân làng nghề $[1,4]$.

Đông Thọ là một xã ngoại thành, nằm ở phía Bắc thành phố Thái Bình, trước đây là xã nằm phía Nam huyện Đông Hưng. Huyện Đông Hưng nằm ở trung tâm của tỉnh Thái Bình. Phía Bắc giáp xã Đông Dương. Phía đông giáp xã Đông Mỹ. Phía Tây giáp sông Trà Lý, Phía Nam giáp xã Đông Hòa. Xã Đông Thọ, thành phố Thái Bình, tỉnh Thái Bình có nghề làm miến dong lâu đời.

Đông Thọ với 321 hộ tham gia hoạt động làng nghề, hàng năm thu hút từ 350 đến 500 lao động. Tính đến 6 tháng đầu năm 2018, giá trị sản xuất hàng hóa tại xã đạt 32,5 tỷ đồng, trong đó giá trị sản xuất hàng hóa của các hộ chế biến lương thực thực phẩm là 29,6 tỷ đồng [2,5]. Trước kia, làm miến còn thủ công, sản xuất còn manh mún, nhỏ lẻ nên không đủ trang trải cho cuộc sống hàng ngày. Thu nhập thấp nên nhiều hộ đã bỏ nghề. Hiện nay, các gia đình đã mạnh dạn đầu tư máy móc, trang thiết bị làm miến mang lại năng suất và thu nhập cho người dân. Từ dây chuyền sản xuất miến công nghiệp cùng với kinh nghiệm của thợ làng nghề, mỗi cơ sở sản xuất miến có thể cho ra từ 1-1,5 tấn miến/ngày [5]. Năng suất cao hơn cũng đồng nghĩa với thu nhập của người làm miến tăng lên. Không chỉ làm tăng thu nhập cho người dân, nghề làm miến dong đã tạo việc làm cho gần 200 người trong thôn. Bình quân mỗi tháng mang lại thu nhập từ 3-3,5 triệu đồng/người. Ngay cả những người già và trẻ nhỏ trong xã cũng có thêm thu nhập từ 100.000-150.000 đồng/ngày từ những công việc hàng ngày như phơi miến, bó miến. Phát triển làng nghề đã giúp Đông Thọ thay đổi nhanh chóng, đời sống người dân được cải thiện rõ rệt.

Việc định hướng không gian, quản lý nước thải sản xuất miến dựa vào cộng đồng tại làng nghề Đông Thọ, tỉnh Thái Bình là cần thiết.

\section{Phương pháp nghiên cứu}

Các phương pháp được sử dụng trong nghiên cứu nhằm tổng hợp cơ sở dữ liệu thu thập các số liệu về điều kiện tự nhiên và kinh tế - xã hội của xã Đông Thọ. Phương pháp điều tra, khảo sát thực địa tham vấn các cấp chính quyền và cộng đồng dân cư các thông tin về hiện trạng môi trường, cơ cấu quản lý, tổ chức quản lý môi trường tại xã Đông Thọ với 2 thôn Thống Nhất và Đoàn Kết với 50 phiếu điều tra/thôn. Phương pháp thống kê, xử lý số liệu tổng hợp thông tin số liệu, tính toán, xử lý số liệu thống kê dựa trên kết quả đo đạc, phân tích thu được; các số liệu được xử lý bằng phần mềm Excel. Phương pháp bản đồ sử dụng tư liệu hoàn thiện bản đồ vị trí khu vực nghiên cứu. Dùng các công cụ phần mềm Mapinfo để bước đầu tiếp cận, xây dựng sơ đồ định hướng không gian lãnh thổ. Phương pháp đánh giá dựa vào cộng đồng đánh giá nhận thức, hiện trạng quản lý môi trường của các cấp chính quyền và cộng đồng dân cư để đề xuất các giải pháp quản lý và giảm thiểu ô nhiễm môi trường.

Thu thập mẫu và các phương pháp phân tích đánh giá. Mẫu nước tại địa điểm nghiên cứu được thu thập như trong Hình 1.

Phương pháp thu thập mẫu áp dụng theo TCVN 6663-1:2011 được thực hiện tại tháng 10 năm 2018. COD được xác định bằng phương pháp SMEWW5220B:2012 đối với nước mặt và SMEWW5220B:2012 đối với nước giếng, $\mathrm{BOD}_{5}$ được xác định bằng phương pháp SMEWW5210B:2012, $\mathrm{NH}_{4}{ }^{+}$được xác định bằng phương pháp TCVN 5988:1995, $\mathrm{NO}_{2-}$ được xác định bằng phương pháp SMEWW 4500- $\mathrm{NO}_{2}$ .B:2012, $\mathrm{NO}_{3-}$ được xác đinh bằng phương pháp

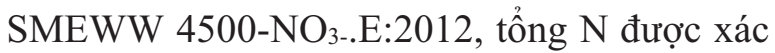
định bằng phương pháp SMEWW 4500$\mathrm{N} . \mathrm{C}: 2012, \mathrm{PO}_{4}{ }^{3-}$ và Tổng $\mathrm{P}$ được phân tích bằng phương pháp SMEWW 4500-P B\&D:2012. Các thông số khác cũng được đo theo tiêu chuẩn của SMEWW và TCVN. 


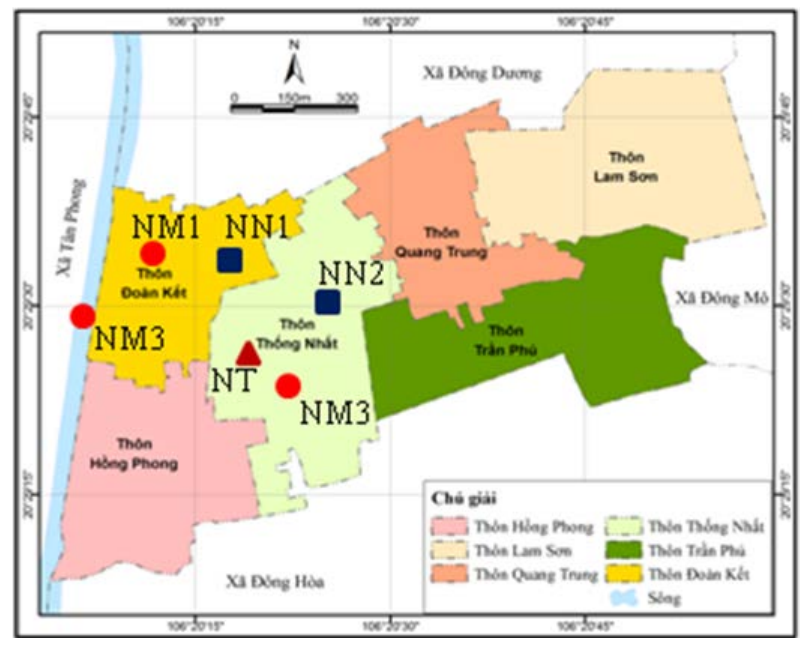

Hình 1. Vị trí các điểm lấy mẫu

Trong đó NM là các điểm lấy mẫu nuớc mặt (Mẫu NM1, NM2 là nuớc ao của hộ tại thôn Đoàn Kết và thôn Thống Nhất, NM3 là mẫu nước ở sông), $\mathbf{\square}$ là các điểm lấy mẫu nuớc ngầm (Mẫu NN1 và NN2 là mẫu nước giếng của 2 gia đình ở thôn Đoàn Kết và Thống Nhất), $\mathbf{\Delta}$ NT là điểm lấy mẫu nước thải tù hộ gia đình sản xuất miến

Đối tượng nghiên cứu tập trung vào vấn đề nước thải sản xuất và quản lý ô nhiễm nước thải sản xuất tại xã Đông Thọ, thành phố Thái Bình, tỉnh Thái Bình.

\section{Kết quả và thảo luận}

\subsection{Quy trình sản xuất miến và chất thải}

Củ dong riềng sau khi thu hoạch về được cho vào máy rửa để loại bỏ đất cát bẩn, sau đó chuyển vào máy nghiền. Tại đây, dong giềng sẽ được nghiền kỹ thành bột ướt. Trong bột dong giềng ướt vẫn còn nhiều tạp chất, chưa thể dùng để chế biến ngay được, cần phải làm sạch bằng

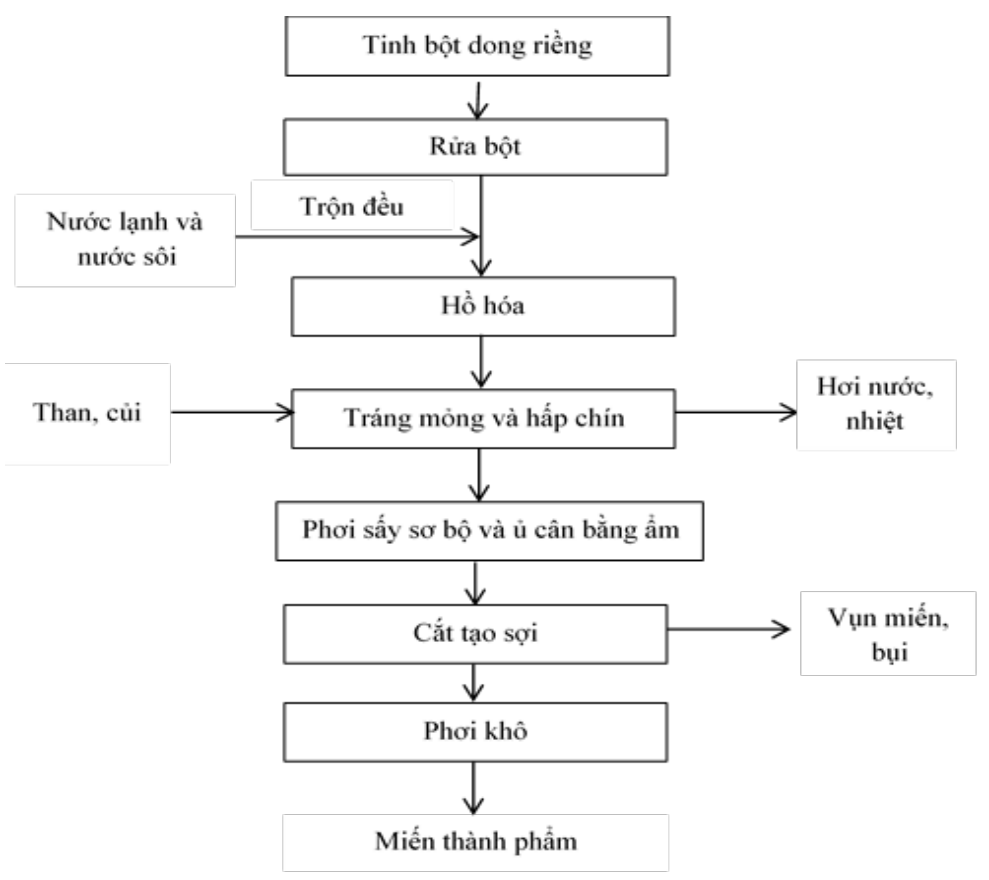

cách rửa với nước. Bột thường được làm sạch 3 lần như vậy. Kết thúc công đoạn rửa, bột thu được đã sạch nhưng chưa trắng. Để làm trắng bột, người ta thường cho $100 \mathrm{~g} \mathrm{NaHSO}_{3}$ (là hóa chất được phép sử dụng trong thực phẩm) được pha trong 50 lít nước sạch vào thùng, khuấy đều và ngâm bột trong 10 - 12 giờ, sau đó xả nước, rửa sạch. Tinh bột thu được sẽ được cải thiện đáng kể độ trắng, tinh bột sẽ được sử dụng vào việc sản xuất miến. Quy trình sản xuất miến được thể hiện ở hình 2.
Hình 2. Quy trình sản xuất miến 


\section{BÀI BÁO KHOA HỌC}

Quy trình sản xuất miến đi kèm là các chất thải từ trong các công đoạn sản xuất. Lượng thải chủ yếu là nước thải sản xuất, chi tiết theo bảng 1 .

Bảng 1. Danh mục chất thải chính sinh ra tù quá trình sản xuất miến dong

\begin{tabular}{|c|c|c|}
\hline TT & Các công đoạn & Loại chất thải phát sinh \\
\hline 1 & Nhập nguyên liệu (tinh bột dong riềng) & $\begin{array}{l}\text { Bụi } \\
\text { Khí thải từ xe vận chuyển } \\
\text { Bao bì nguyên liệu }\end{array}$ \\
\hline 2 & Ngâm, tẩy bột & $\begin{array}{l}\text { Nước thải rửa bột có lẫn hóa chất } \\
\text { Nước thải thau rửa bể bột, vệ sinh máy khuấy } \\
\text { Bột thừa }\end{array}$ \\
\hline 3 & Hồ hóa & $\begin{array}{l}\text { Xỉ than } \\
\text { Nước thải thau rửa thùng nấu bột } \\
\text { Nước thải vệ sinh máy móc }\end{array}$ \\
\hline 4 & Tráng mỏng và hấp chín & $\begin{array}{l}\text { Dầu thải } \\
\text { Xỉ than }\end{array}$ \\
\hline 5 & Phơi miến & \\
\hline 6 & Thái sợi & $\begin{array}{l}\text { Nước thải vệ sinh máy móc, dầu thải } \\
\text { Vụn miến }\end{array}$ \\
\hline 7 & Đóng gói thành phẩm & Bao bì nilon, dây nilon, lạt, $\ldots$ còn dư thừa \\
\hline 8 & Vận chuyển, tiêu thụ thành phẩm & Khói bụi thải từ phương tiện vận chuyển \\
\hline
\end{tabular}

\section{2. Đánh giá chất lượng môi trường nước}

Do trong quy trình sản xuất miến dong, lượng thải ra môi trường lớn nhất là nước thải từ các công đoạn làm tinh bột dong riềng với hàm lượng chất hữu cơ cao, không được xử lý trước khi xả thải gây ô nhiễm nước. Kết quả phân tích nước thải sản xuất được thể hiện ở bảng 2.

Bảng 2. Kết quả phân tích nuớc thải tại cơ sở sản xuất miến dong tại xã Đông Thọ

\begin{tabular}{clccc}
\hline STT & \multicolumn{1}{c}{ Thông số } & Đơn vị & Kết quả phân tích nước thải & QCVN 40:2011 \\
\hline 1 & $\mathrm{pH}$ & - & 4,6 & $5,5-9$ \\
2 & $\mathrm{COD}$ & $\mathrm{mgO}_{2} / 1$ & 172 & 150 \\
3 & $\mathrm{BOD}_{5}\left(20^{\circ} \mathrm{C}\right)$ & $\mathrm{mgO}_{2} / 1$ & 111 & 50 \\
4 & $\mathrm{NH}_{4}{ }^{+}$(theo nito) & $\mathrm{mg} / 1$ & 6,77 & 10 \\
5 & Tổng N & $\mathrm{mg} / 1$ & 22,0 & 40 \\
6 & Tổng P & $\mathrm{mg} / 1$ & 2,02 & 6 \\
7 & TSS & $\mathrm{mg} / 1$ & 850 & 100 \\
\hline
\end{tabular}

Thời điểm lấy mẫu thí nghiệm trên tại cơ sở sản xuất miến dong xã Đông Thọ vào tháng 10 năm 2018, là thời gian chưa cao điểm sản xuất miến trong năm tại xã. Tuy nhiên, các chỉ tiêu như TSS, $\mathrm{COD}, \mathrm{BOD}_{5}$ đều cao hơn nhiều lần so với quy chuẩn cho phép (QCVN 40:2011/BTNMT). Cụ thể, TSS cao hơn gấp 8,5 lần quy chuẩn, $\mathrm{COD}$ cao hơn 1,15 lần và $\mathrm{BOD}_{5}$ cao gấp 2,22 lần so với quy chuẩn. Với lượng nước thải bị ô nhiễm này, khi xả vào môi trường trong thời gian dài mà không được xử lý sẽ gây ảnh hưởng nghiêm trọng. Nước thải thải trực tiếp ra môi trường khiến cho các ao hồ, kênh rạch trong khu vực sản xuất bị ô nhiễm chất hữu cơ nặng nề. Các kênh rạch lâu ngày không được nạo vét, bị ứ đọng các chất ô nhiễm, sự phân hủy chất hữu cơ diễn ra mạnh mẽ, sinh mùi khó chịu. Thêm vào đó lượng nước thải sinh hoạt hàng ngày cũng thường được thải trực tiếp ra các kênh nước thải nên sự ô nhiễm lại ngày càng tăng thêm. 
Bảng 3. Kết quả phân tích mẫu nước mặt tại làng nghè làm miến xã Đông Tho

\begin{tabular}{|c|c|c|c|c|c|c|c|c|c|}
\hline \multirow{2}{*}{ TT } & \multirow{2}{*}{ Chỉ tiêu } & \multirow{2}{*}{ Đơn vị } & \multirow{2}{*}{ NM1 } & \multirow{2}{*}{ NM2 } & \multirow{2}{*}{ NM3 } & \multicolumn{4}{|c|}{ QCVN 08-MT:2015/BTNMT } \\
\hline & & & & & & A1 & A2 & B1 & B2 \\
\hline 1 & Nhiệt độ & ${ }^{\circ} \mathrm{C}$ & 22,5 & 23,6 & 23,1 & - & - & - & - \\
\hline 2 & $\mathrm{pH}$ & - & 7,06 & 8,1 & 7,22 & $6-8,5$ & $6-8,5$ & $5,5-9$ & $5,5-9$ \\
\hline 3 & DO & $\mathrm{mg} / \mathrm{l}$ & 3,3 & 4,88 & 3,15 & $\geq 6$ & $\geq 5$ & $\geq 4$ & $\geq 2$ \\
\hline 4 & TSS & $\mathrm{mg} / \mathrm{l}$ & 135 & 56 & 172 & 20 & 30 & 50 & 100 \\
\hline 5 & COD & $\mathrm{mg} / \mathrm{l}$ & 342 & 225 & 156 & 10 & 15 & 30 & 50 \\
\hline 6 & $\mathrm{BOD}_{5}\left(20^{\circ} \mathrm{C}\right)$ & $\mathrm{mg} / \mathrm{l}$ & 198 & 130 & 110 & 4 & 6 & 15 & 25 \\
\hline 7 & $\begin{array}{l}\mathrm{PO}_{4}^{3-} \\
\text { (tính theo P) }\end{array}$ & $\mathrm{mg} / \mathrm{l}$ & 0,69 & 0,62 & 0,75 & 0,1 & 0,2 & 0,3 & 0,5 \\
\hline 8 & $\begin{array}{l}\mathrm{NH}_{4}^{+} \\
\text {(tính theo N) }\end{array}$ & $\mathrm{mg} / \mathrm{l}$ & 0,938 & 0,688 & 9,038 & 0,3 & 0,3 & 0,9 & 0,9 \\
\hline 9 & $\begin{array}{l}\mathrm{NO}_{2}^{-} \\
(\text {tính theo N) }\end{array}$ & $\mathrm{mg} / \mathrm{l}$ & 0,021 & 0,006 & 0,221 & 0,05 & 0,05 & 0,05 & 0,05 \\
\hline 10 & $\begin{array}{l}\mathrm{NO}_{3}^{-} \\
\text {(tính theo } \mathrm{N} \text { ) }\end{array}$ & $\mathrm{mg} / \mathrm{l}$ & 6,39 & 1,46 & 81 & 2 & 5 & 10 & 15 \\
\hline 11 & $\mathrm{Cl}^{-}$ & $\mathrm{mg} / \mathrm{l}$ & 115 & 137 & 195 & 250 & 350 & 350 & - \\
\hline
\end{tabular}

Hầu hết các mẫu nước đều vượt tiêu chuẩn cho phép các thông số TSS, $\mathrm{BOD}_{5}, \mathrm{COD}$, $\mathrm{PO}_{4}{ }^{3}-, \quad \mathrm{NH}_{4}^{+}, \quad \mathrm{NO}_{2}^{-}, \quad \mathrm{NO}_{3}^{-} \quad(\mathrm{QCVN}$ 08MT:2015/BTNMT - Quy chuẩn kỹ thuật quốc gia về chất lượng nước mặt, cột B1) về quy chuẩn nước mặt trên sông, hồ, kênh mương phục vụ cho mục đích tưới tiêu nông nghiệp và các mục đích khác yêu cầu chất lượng nước tương tự. Hàm lượng chất rắn lơ lửng trong nước vượt quá quy chuẩn cho phép từ 1,12 đến 3,44 lần, dao động từ 56 đến $172 \mathrm{mg} / 1$. Các chỉ tiêu $\mathrm{BOD}_{5}$ và $\mathrm{COD}$ cũng vượt quá quy chuẩn nhiều lần: COD trong nước dao động từ 156 đến $342 \mathrm{mg} / 1$, gấp 5,2 đến 11,4 lần, BOD $_{5}$ từ 110 đến $198 \mathrm{mg} / \mathrm{l}$, gấp 7,3 đến 13,2 lần quy chuẩn cho phép. Hàm lượng amoni trong nước tại mẫu NM2 $\mathrm{NH}_{4}{ }^{+}=$ $0,688 \mathrm{mg} / \mathrm{l}$, nằm trong quy chuẩn cho phép, còn hai mẫu NM1 và NM3 đều vượt quá giới hạn, đặc biệt là mẫu NM3 vượt tiêu chuẩn tới hơn 10 lần. Chỉ tiêu nitrit và nitrat trong các mẫu NM1 và $\mathrm{NM} 2$ đều nằm trong giới hạn cho phép, còn mẫu NM3 có hàm lượng vượt quá tiêu chuẩn cho phép nhiều lần. Hàm lượng $\mathrm{PO}_{4}{ }^{3-}$ tại các vị trí lấy mẫu khá cao, vượt giới hạn cho phép từ 2,07 đến 2,5 lần. Lượng oxi hòa tan trong nước khá thấp, chỉ có mẫu NM2 là đạt tiêu chuẩn cho phép.

Nước ngầm tại khu vực hai thôn Đoàn Kết và Thống Nhất có dấu hiệu bị ô nhiễm (dựa vào QCVN 09-MT:2015/BTNMT - Quy chuẩn kỹ thuật quốc gia về chất lượng nước dưới đất). Chỉ số pemanganat và $\mathrm{NO}_{3}{ }^{-}$của cả hai mẫu đều vượt quá giới hạn cho phép, thể hiện ở bảng 4. Nguồn nước giếng trong địa bàn hai thôn hầu hết đều là nước giếng khoan với độ sâu khoảng từ 8 đến 12 $\mathrm{m}$, với các kênh nước thải không có kè bằng bê tông hay các vật liệu khác, một phần các chất ô nhiễm bị tích tụ lâu ngày đã ngấm xuống tầng nước ngầm nông. Thêm vào đó, hệ thống xử lý sơ bộ với 3 bể lắng tại các hộ gia đình được hướng dẫn là không xây gạch, bê tông để ngấm tự nhiên một phần vào đất nên có thể cũng gây ra hiện tượng các chất ô nhiễm thấm xuống tầng nước ngầm, khiến cho nguồn nước bị ô nhiễm. 
Bảng 4. Kết quả phân tích mẫu nước ngầm tại làng nghề làm miến xã Đông Tho

\begin{tabular}{|c|c|c|c|c|c|}
\hline STT & Chỉ tiêu & Đơn vị & NN1 & NN2 & $\begin{array}{c}\text { QCVN 09- } \\
\text { MT:2015/BTNMT }\end{array}$ \\
\hline 1 & Nhiệt độ & ${ }^{\circ} \mathrm{C}$ & 26,2 & 27,0 & - \\
\hline 2 & $\mathrm{pH}$ & - & 6,69 & 6,45 & $5,5-8,5$ \\
\hline 3 & Chỉ số pemanganat & $\mathrm{mg} / \mathrm{l}$ & 7,5 & 7,9 & 4 \\
\hline 4 & $\begin{array}{l}\mathrm{PO}_{4}^{3-} \\
\text { (tính theo P) }\end{array}$ & $\mathrm{mg} / \mathrm{l}$ & 0,12 & 0,17 & - \\
\hline 5 & $\begin{array}{l}\mathrm{NH}_{4}^{+} \\
(\text {tính theo N)}\end{array}$ & $\mathrm{mg} / \mathrm{l}$ & 0,813 & 0,6 & 1,0 \\
\hline 6 & $\begin{array}{l}\mathrm{NO}_{2}^{-} \\
\text {(tính theo N) }\end{array}$ & $\mathrm{mg} / \mathrm{l}$ & 0,014 & 0,211 & 1,0 \\
\hline 7 & $\begin{array}{l}\mathrm{NO}_{3}^{-} \\
\text {(tính theo } \mathrm{N} \text { ) }\end{array}$ & $\mathrm{mg} / \mathrm{l}$ & 25 & 35 & 15 \\
\hline 8 & $\mathrm{Cl}^{-}$ & $\mathrm{mg} / \mathrm{l}$ & 6 & 7 & 250 \\
\hline 9 & $\mathrm{Ca}^{2+}$ & $\mathrm{mg} / \mathrm{l}$ & 24,32 & 26,27 & - \\
\hline
\end{tabular}

\subsection{Thục trạng quản lý nước thải tại các co sở sản xuất}

Hiện nay, nguồn nước thải sản xuất tại làng nghề làm miến dong xã Đông Thọ đã được thu gom tách riêng với nguồn nước sinh hoạt của gia đình để xử lý sơ bộ trước khi xả ra môi trường, tuy nhiên hệ thống xử lý sơ bộ, không đạt tiêu chuẩn và không có khả năng xử lý hiệu quả. Nguồn nước thải sinh hoạt trong hộ gia đình được đổ vào cống và dẫn trực tiếp tới kênh, mương trong khu vực thôn mà không qua hệ thống xử lý nào. Quy trình xử lý nước thải qua hệ thống bể xây dựng gồm 3 ngăn: lắng tự nhiên, lọc cát, lọc than đá, các bể được xây dựng không trát để nước thải ngấm một phần vào lòng đất. Các lớp vật liệu lọc từ khi bắt đầu hoạt động đều chưa được thay mới, lớp bùn không được nạo vét theo chu kì nên hệ thống hoạt động không hiệu quả, không có khả năng xử lý nước thải. Bên cạnh đó, vào thời gian sản xuất cao điểm, lượng nước thải được đưa vào bể liên tục, không đủ thời gian để lắng các chất lơ lửng mà cứ thế qua các bể rồi đổ ra hệ thống mương thải chung của thôn. Hiện tại, thôn Thống Nhất có 90 hộ sản xuất quy mô lớn, thôn Đoàn Kết có 81 hộ sản xuất quy mô lớn, thôn Hồng Phong có 50 hộ sản xuất quy mô vừa, thôn Trần Phú, Tân Phong và Lam Sơn lần lượt có 27 hộ, 36 hộ, 37 hộ sản xuất quy mô nhỏ.

\subsection{Nhận thức cộng đồng trong công tác quản lý môi trưòng}

Kết quả cho thấy, việc nhận thức về vấn đề ô nhiễm hiện tại của làng nghề chủ yếu là do nước thải sản xuất miến dong được thể hiện ở hình 3. Tất cả 6 thôn đều có tỷ lệ (\%) đánh giá nguyên nhân gây ô nhiễm môi trường nước chủ yếu là do nước thải sản xuất miến (thôn Thống Nhất: $70 \%$, thôn Đoàn Kết: 74\%, thôn Trần Phú: 44\%, thôn Quang Trung: 50\%, thôn Lam Sơn: 58\% ). Về tác hại của ô nhiễm, hầu hết các thôn đều nhận thấy môi trường ô nhiễm, song về tác hại cộng đồng chưa đánh giá ở mức độ rất nguy hiểm nên nảy sinh tâm lý "sản xuất và sống chung với ô nhiễm”. Kết quả đánh giá ở hình 4 chỉ ra rằng 43,33\% số hộ gia đình được khảo sát để nước thải sản xuất chảy trực tiếp vào hệ thống mương thoát chung của xã, 23,33\% chảy qua bể tự hoại, 13,33\% chảy qua bể lọc cát kết hợp qua bể tự hoại, sau đó chảy trực tiếp vào mương thoát chung của xã. 3,34\% có hệ xử lý nước thải sản xuất. Về phía những người không sản xuất có hai ý kiến: bức xúc về việc xả thải và cũng có ý kiến thông cảm với người sản xuất. Về phía những người có sản xuất thì không muốn nói đến khía cạnh ô nhiễm hoặc cho rằng đó là tình trạng chung của cả làng, không có cách nào khác là xả thải như hiện tại; tại hộ gia đình đã có hệ thống xử lý nước thải (thực tế là các bể lắng) như xã hướng dẫn trong nhiều năm qua là đủ. Cán bộ địa phương, những người có trách nhiệm trong việc quản lý môi trường ở xã chưa có phương thức chặt chẽ trong thu gom và xử lý nước thải 
sản xuất, vì thế nguồn nước thải thải vào mương thoát chung của xã không qua xử lý gây ảnh hưởng môi trường và sức khỏe người dân. Mặt khác, những người chịu trách nhiệm quản lý này thiếu kiến thức chuyên môn cần thiết cho công việc của mình, thường phải làm việc kiêm nhiệm. Do đó việc tuyên truyền cho người dân hiểu trách nhiệm và nghĩa vụ của mình trong việc bảo vệ môi trường là không tốt. Phản ứng cũng khá bức xúc với vấn đề ô nhiễm song cho

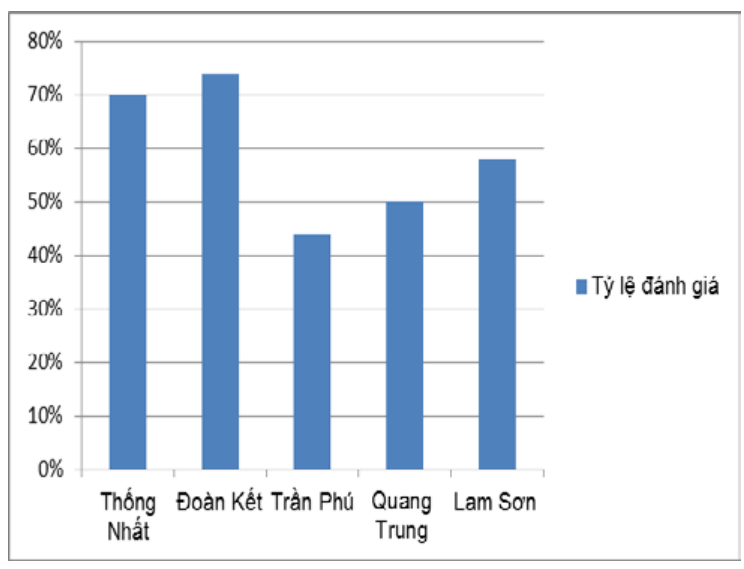

Hình 3. Tỷ lệ người dân đánh giá nguyên nhân gây ô nhiễm do nước thải sản xuất

3.5. Giải pháp định hướng không gian sản xuất

Theo sơ đồ định hướng tập trung nguồn thải tại Hình 5 cần xây dựng khu tập trung thu gom nước thải phải đảm bảo không gây ô nhiễm ảnh hưởng đến sức khỏe và sinh hoạt của người dân. Bố trí nơi thu gom ở cuối hướng gió, xa khu dân cư, gần đường giao thông, thuận tiện cho việc chuyên chở, có hệ thống cấp thoát nước đầy đủ và thuận tiện. Vị trí của khu thu gom nước thải tập trung có thể lựa chọn vị trí rộng rãi, nằm ở rằng nếu không sản xuất thì không có thu nhập, và cũng không có vốn để đầu tư cho các giải pháp cải thiện môi trường, đồng thời cho rằng có rất nhiều đoàn về nghiên cứu, khảo sát song đến nay vẫn chưa có giải pháp nào là khả thi hoặc có đề xuất thì chi phí cao, không thực hiện được và $\mathrm{xu}$ hướng vẫn thụ động vào sự giải quyết từ cấp trên. Chính quyền địa phương thường xuyên bị yêu cầu chỉ đạo chấm dứt sản xuất từ các thôn xóm, xã lân cận.

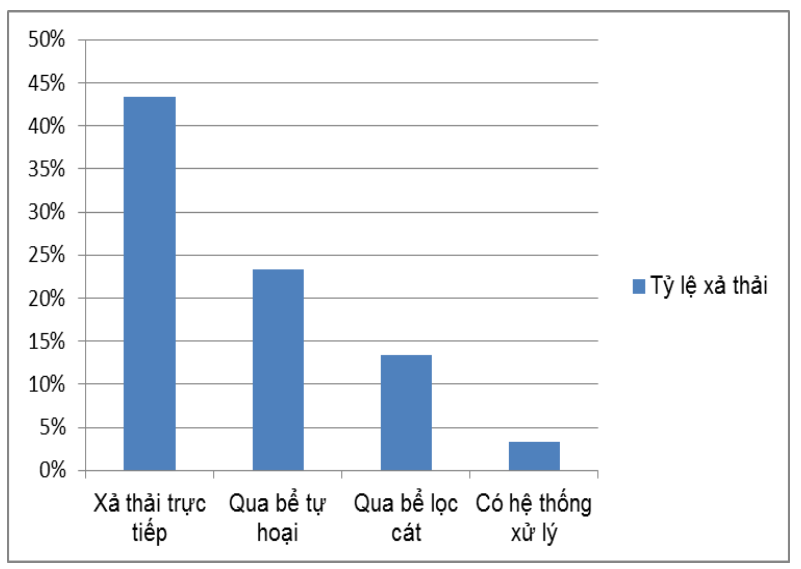

Hình 4. Hình thức xả thải của các hộ sản xuất

gần các cơ sở sản xuất nhỏ lẻ. Khi tiến hành xây dựng quy hoạch cần quan tâm đến một số vấn đề như: điều kiện thực tế của địa phương, nguyện vọng của hộ sản xuất, và những yêu cầu cần đáp ứng (về mặt bằng, vấn đề môi trường, vấn đề thị trường và thương hiệu sản phẩm, vấn đề vệ sinh an toàn thực phẩm,...).

Trong hình 6 mô tả sơ đồ định hướng không gian sản xuất tập trung tại xã Đông Thọ với các thôn tập trung sản xuất và có các trạm xử lý nước thải tập trung. 


\section{BÀI BÁO KHOA HỌC}

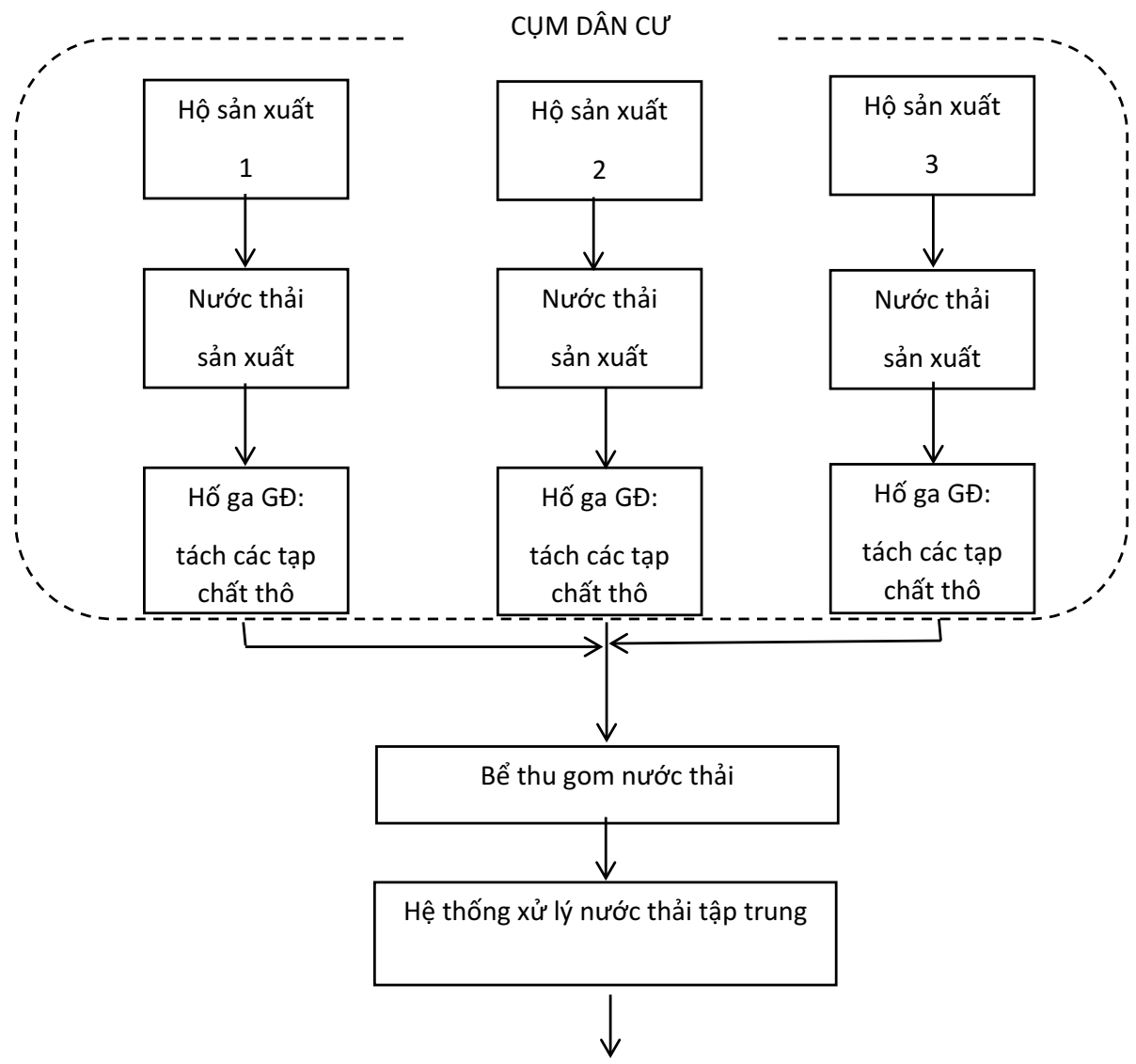

Nước thải đã xử lý

Hình 5. So đồ định hướng tập trung nguồn thải

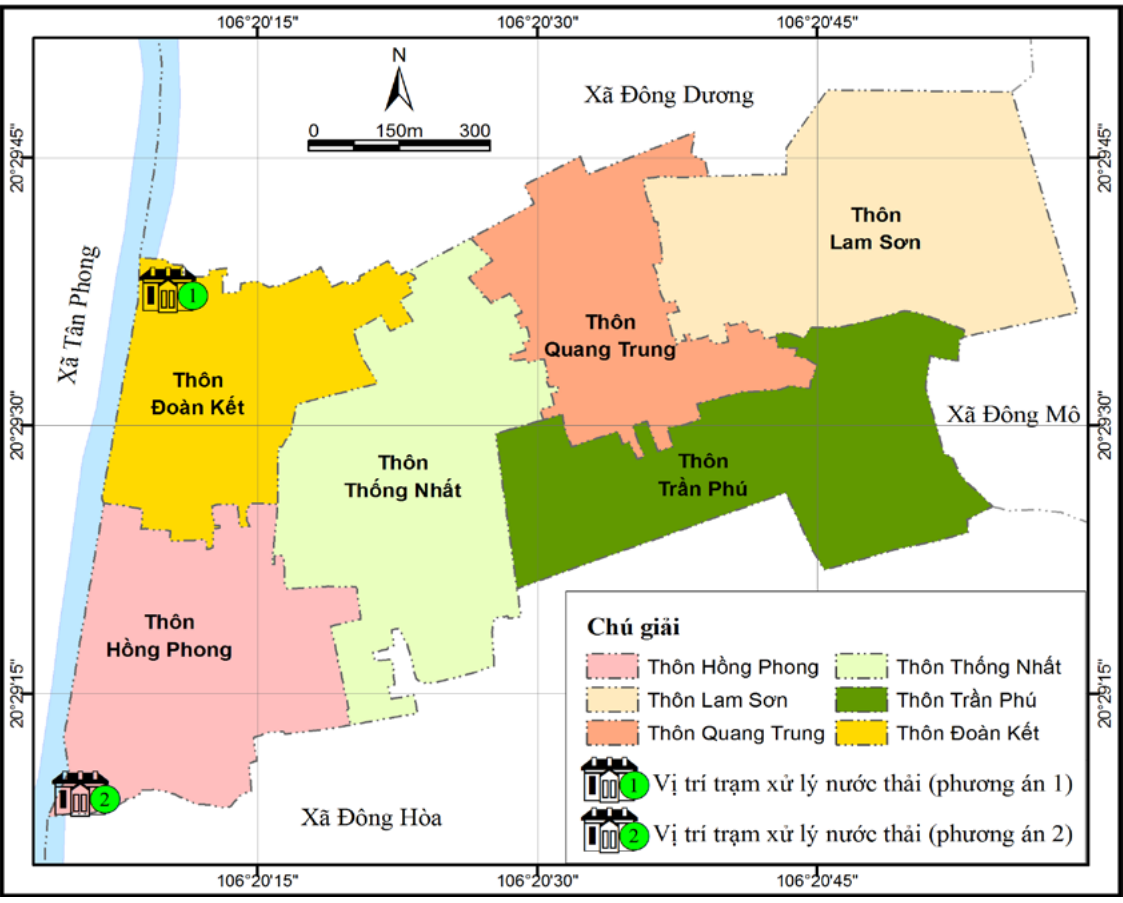

Hình 6. So đồ định hướng không gian sản xuất tập trung tại xã Đông Thọ 
Đối với những hộ sản xuất lớn thì cần có định hướng về việc sử dụng đất trong sản xuất một cách hợp lý, đảm bảo sự thoáng mát, vệ sinh trong môi trường sản xuất. Do lưu lượng nước thải ra tại các hộ gia đình này lớn nên cần áp dụng những mô hình xử lý môi trường ngay tại nhà. Các cơ sở sản xuất với mức tiêu thụ $>1$ tấn bột/ngày là đối tượng phù hợp để áp dụng mô hình xử lý nước thải tại chỗ. Với mô hình phân tách khu nhà ở và khu sản xuất, hoạt động sinh hoạt của gia đình sẽ không bị ảnh hưởng nhiều bởi tiếng ồn và các khí độc hại sinh ra trong quá trình các máy móc hoạt động. Khu sản xuất miến cũng được bố trí lại các khu vực hoạt động sao cho hợp lý với quy trình làm miến nhất. Bể ngâm bột được xây dựng gần vị trí kho nguyên liệu và bể nước để thuận tiện cho việc chuyển bột vào bể ngâm, kế bên cạnh là bể chứa bột đã sơ chế để chuẩn bị cho hoạt động hồ hóa và tráng bánh. Kho để phên được bố trí gần máy tráng và máy cắt miến để sau khi tráng bánh dễ dàng lấy phên phơi, sau đó chuyển vào máy cắt miến, thái sợi, phơi một lần nữa và đưa vào kho thành phẩm để chờ tiêu thụ. Bố trí các bể và máy móc như vậy tiết kiệm được nhiều thời gian di chuyển giữa các công đoạn sản xuất. Hệ thống thu gom nước thải được xây dựng gần mương thải chung để nước thải đầu ra chảy thẳng vào mương.

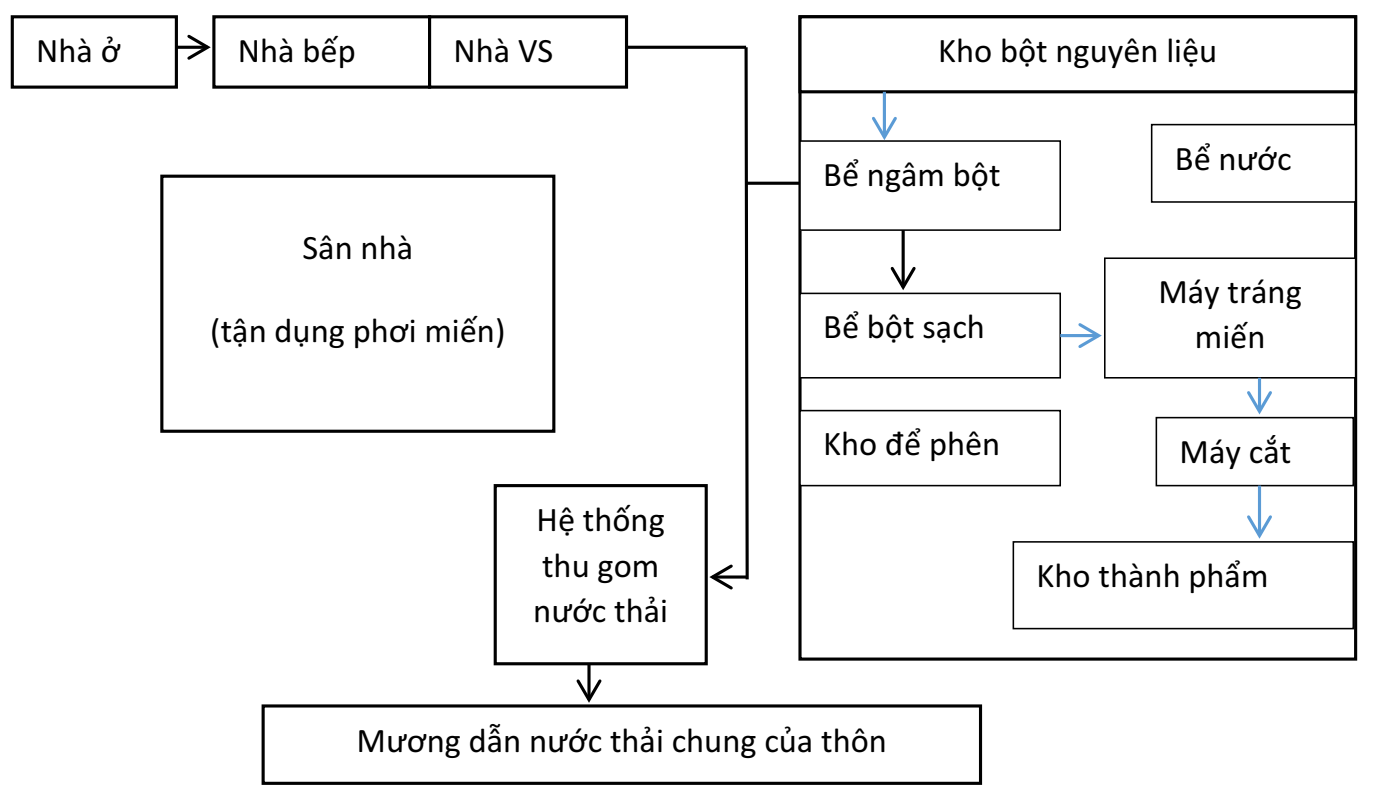

Hình 7. So đồ định hướng sủ dụng đất hộ sản xuất và hệ thống thu gom nước thải

\subsection{Giải pháp phát huy vai trò của cộng đồng trong quản lý môi truò̀ng}

Tăng cường hoạt động giám sát của cộng đồng đối với môi trường làng nghề; phát hiện và kiểm tra các hộ sản xuất làng nghề tiếp tục gây ô nhiễm môi trường nghiêm trọng; Yêu cầu các làng nghề triển khai áp dụng các biện pháp cần thiết nhằm giảm thiểu ô nhiễm. Đồng thời nâng cao năng lực đội ngũ quản lý môi trường tại địa phương, đồng thời thiết lập hệ thống quản lý môi trường làng, xã với sự tham gia của đại diện cho hộ sản xuất làng nghề. Khuyến khích các cơ sở sản xuất trong làng nghề áp dụng các giải pháp sản xuất sạch hơn để giảm lượng phát thải và mang lại hiệu quả kinh tế cao; Xây dựng tiêu chí "Làng nghề xanh" nhằm xếp loại cho các làng nghề BVMT theo hướng phát triển bền vững.

Xã hội hóa công tác BVMT làng nghề nhằm huy động và phát huy vai trò của cộng đồng trong BVMT làng nghề; Thực hiện các hoạt động tham vấn cộng đồng thường xuyên trong BVMT làng nghề; thu thập những ý kiến của cộng đồng về những vấn đề môi trường đang diễn ra tại địa phương. Tăng cường giáo dục, tuyên truyền nâng cao nhận thức và phổ biến các quy định pháp luật BVMT cho cộng đồng dân 


\title{
BÀI BÁO KHOA HỌC
}

cư trong các làng nghề; Tuyên dương những hộ gia đình làm tốt công tác BVMT [2,5].

\section{Kết luận}

Đông Thọ là một xã của tỉnh Thái Bình chuyên về sản xuất miến, hiện gây ô nhiễm môi trường nước. Kết quả phân tích mẫu nước thải sản xuất so sánh với quy chuẩn cho phép (QCVN 40:2011/BTNMT), TSS cao hơn gấp 8,5 lần quy chuẩn, $\mathrm{COD}$ cao hơn 1,15 lần và $\mathrm{BOD}_{5}$ cao gấp 2,22 lần. Hầu hết các mẫu nước mặt đều vượt tiêu chuẩn cho phép (QCVN 08-
MT:2015/BTNMT), TSS vượt 1,12-3,44 lần, COD vượt 5,2-11,4 lần, $\mathrm{BOD}_{5}$ vượt 7,3-13,2, $\mathrm{NH}_{4}{ }^{+}$vượt 10 lần, $\mathrm{PO}_{4}{ }^{3-}$ vượt 2,07-2,5 lần, lượng oxy hòa tan trong nước khá thấp không đạt tiêu chuẩn. Nước ngầm tại khu vực hai thôn Đoàn Kết và Thống Nhất bị ô nhiễm về chỉ số pemanganat và $\mathrm{NO}_{3}{ }^{-}$. Giải pháp định hướng không gian lãnh thổ khu vực sản xuất, đồng thời phát huy vai trò cộng đồng trong quản lý và cải thiện môi trường làng nghề.

\section{Tài liệu tham khảo}

1. Báo cáo chuyên đề (2010), Điều tra tổng thể hiện trạng vùng chế biến nông thủy sản, Truờng Đại học Bách Khoa Hà Nội: Viện Khoa học công nghệ và Môi truờng.

2. Bộ Nông nghiệp và Phát triển nông thôn (2010), Danh sách các làng nghề Việt Nam.

3. Bộ Tài nguyên và Môi trường (2008), Báo cáo môi truờng quốc gia 2008 - Môi trường làng nghề Việt Nam.

4. Đặng Kim Chi (2005), Làng nghề Việt Nam và Môi trường. NXB Khoa hoc và Kỹ thuât.

5. Hiệp hội làng nghề Việt Nam (2009), Kết quả khảo sát hiện trạng sản xuất và môi trường một số làng nghề trong cả nước.

6. Phạm Thị Tố Oanh (2016), Quản lý môi trương làng nghề dựa vào cộng đồng, đề án 3 năm 2014 - 2016. Liên minh hợp tác xã Việt Nam.

7. UBND xã Đông Thọ (2015-2017), Báo cáo tổng kết xây dụng nông thôn mới xã Đông Thọ giai đoạn $2011-2014$.

\section{WATER ENVIRONMENTAL ASSESSMENT AND THE SPATIAL DI- VISION OF VERMICELLI PRODUCTION FOR DONG THO VILLAGE IN THAI BINH PROVINCE}

\section{Pham Thi To Oanh ${ }^{1}$}

${ }^{1}$ Vietnam Cooperative Alliance

\begin{abstract}
Dong Tho is a commune of Thai Binh City in Thai Binh province. The major occupation is the production of vermicelli which is made from edible canna. Analysis results to waste water, shown as TSS higher than permitted standards (QCVN 40:2011/BTNMT) 8,5 times, COD is 1,15 times, $\mathrm{BOD}_{5}$ is 2,22 times. Samples of suface water are higher permitted standards (QCVN 08MT:2015/BTNMT) with TSS is 1,12-3,44 times, COD 5,2-11,4 times, BOD 5 is 7,3-13,2 times, $\mathrm{NH}_{4}^{+}$ is 10 times, $\mathrm{PO}_{3}^{-}$is 2,07-2,5 times. Pemangenat and $\mathrm{NO}_{3}^{-}$in underground water is over permitted standards. Resolutions are also suggested to orient the spatial production in accordance with community-based environmental management, promoting the community's role in order to protect and improve the environment of the village.
\end{abstract}

Keywords: Pollution, Ermicelli production, Spatial division 